\title{
PEMBERDAYAAN MASYARAKAT DESA ADAT DALAM PENCEGAHAN PENYEBARAN COVID-19 DI DESA ADAT APIT YEH MANGGIS KARANGASEM BALI
}

\section{EMPOWERMENT OF THE TASK FORCE OF THE COVID-19 VILLAGE'S CULTURAL BASE IN PREVENTING THE SPREAD OF COVID 19 IN APIT YEH MANGGIS KARANGASEM, BALI}

\author{
N.L.K Sulisnadewi ${ }^{1}$, I Ketut Suardana ${ }^{2}$, I.G.A Ari Rasdini ${ }^{3}$, Ni Nyoman Hartati ${ }^{4}$, IDM \\ Ruspawan ${ }^{5}$, Agus Sri Lestari ${ }^{6}$, I Wayan Candra ${ }^{7}$, I.G.A Harini ${ }^{8}$, I Nyoman Ribek ${ }^{9}$, I.G.K \\ Ngurah ${ }^{10}$ \\ Poltekekes Denpasar Jurusan Keperawatan \\ Email : sulisnadewi337@gmail.com
}

\begin{abstract}
ABSTRAK
Kasus pandemi Covid-19 di Indonesia kian hari terus meningkat. Sampai 3 Mei 2020 sudah tercatat yang positif ada 11.192 kasus, sembuh 1876 kasus, dan meninggal 845 kasus. Di Provinsi Bali data sampai dengan tanggal 3 Mei 2020 menunjukkan jumlah kumulatif pasien positif 262 orang, jumlah pasien yang telah sembuh sejumlah 151 orang dan jumlah pasien yang meninggal sejumlah 4 orang. Salah satu upaya yang dillakukan pemerintah propinsi Bali dalam memutus mata rantai penyebaran covid-19 adalah dengan memberdayakan Satgas Gotong Royong yang dimiliki oleh setiap desa adat di Bali. Tugas utama Satgas Gotong Royong yakni memberdayakan Krama Desa Adat dan Yowana untuk bergotong royong sesama Krama Desa Adat dalam melakukan pencegahan Covid-19. Poltekkes Denpasar merupakan salah satu perguruan tinggi kesehatan yang tentunya memiliki tugas dan peran melakukan pengabdian kepada masyarakat dan perannya sangat dibutuhkan dalam rangka mitigasi pandemic covid-19. Kegiatan pendampingan dan pemberdayaan masyarakat bertujuan untuk untuk mendampingi masyararkat dalam proses penguatan potensi masyarakat dan kapasitas desa adat dalam antisipasi penyebaran covid -19. Sasaran dari pengabdian masyarakat ini adalah satgas covid-19 desa adat Apit Yeh Manggis Karangasem yang berjumlah 25 orang dan masyarakat Desa yang berjumlah $921 \mathrm{KK}$. Kegiatan yang dilakukan yaitu pemberian edukasi kepada satgas, pemberian poster, masker, dan juga penambah daya tahan tubuh untuk anggota satgas covid 19.
\end{abstract}

Kata Kunci : Pemberdayaan - Desa Adat - Pencegahan Covid -19

\begin{abstract}
The cases of the Covid-19 pandemic in Indonesia are continuously increasing. As of May 3, 2020, 11,192 positive cases have been recorded, 1876 cases recovered, and 845 cases died. In Bali Province, data up to May 3 2020 shows the cumulative number of positive patients is 262, the number of patients who have recovered is 151 people and the number of patients who have died is 4 people. One of the efforts made by the Bali provincial government in breaking the chain of the spread of Covid-19 is by empowering the Mutual Cooperation Task Force which is owned by every traditional village in Bali. The main task of the Mutual Cooperation Task Force is to empower people and tennagger in the tradisional village to work together in preventing Covid-19. The Politechnic of health Denpasar is one of the health colleges which certainly has a duty and role to serve the community and its role is very much needed in the context of mitigating the Covid-19 pandemic. Community assistance and empowerment activities aim to assist the community in the process of strengthening community potential and the capacity of traditional villages in anticipating the spread of covid -19. The targets of this community service are the covid-19 task force of the Apit Yeh Manggis Karangasem traditional village, which consists of 25 people and the village community, amounting to 921 families. Activities carried out include providing education to the task force, providing posters, masks, and also enhancing endurance for members of the Covid 19 task force.
\end{abstract}

Keywords : Empowerment - Traditional Villages - Covid -19 Prevention 


\section{PENDAHULUAN}

Infeksi virus Corona disebut COVID-19 (Corona Virus Disease 2019) dan pertama kali ditemukan di kota Wuhan, China pada akhir Desember 2019. Virus ini menular dengan sangat cepat dan telah menyebar ke hampir semua negara, termasuk Indonesia, hanya dalam waktu beberapa bulan.(Lam, Muravez, \& Boyce, 2015)

Kasus pandemi Covid-19 di Indonesia kian hari terus meningkat. Sampai 3 Mei 2020 sudah tercatat yang positif ada 11.192 kasus, sembuh 1876 kasus, dan meninggal 845 kasus. Di Provinsi Bali data sampai dengan tanggal 3 Mei 2020 menunjukkan jumlah kumulatif pasien positif 262 orang, jumlah pasien yang telah sembuh sejumlah 151 orang dan jumlah pasien yang meninggal sejumlah 4 orang. Pada tanggal 3 Mei terjadi pemanbahan kasus postif yg sangat signifikan dibandingkan hari-hari sebelumnya. Penambahan kasus positif Covid19 di Bali sebanyak 25 orang, yakni 22 orang dari transmisi lokal dan 3 orang Pekerja Migran Indonesia (PMI). Dari seluruh kasus di Bali, 90 orang merupakan kasus transmisi lokal, yang menunjukan masih adanya masyarakat yang tidak melakukan upaya pencegahan Covid-19, seperti pemakaian masker, mencuci tangan, dan physical distancing .(LuH Putu Sugiari, 2020). Untuk itu, sekali lagi, dalam menekan kasus transmisi lokal maka masyarakat harus sadar dan disiplin dalam melakukan upaya pencegahan virus ini.

Kegiatan edukasi, sosialisasi maupun pengawasan pencegahan covid19 harus dilakukan sesering mungkin dan secara berkesinambungan. Kegiatan dimaksud tentu tidak bisa dilakukan dengan mengumpulkan masyarakat di masa pandemi ini. Bali memiliki suatu lembaga yang disebut dengan Desa Adat. Desa Adat ini memiliki fungsi strategis dan memiliki otoritas dalam mengatur kehidupan masyarakat adatnya. Desa Adat yang lahir karena tuntutan kodrati manusia sebagai mahluk social akan sangat efektif apabila diberdayakan untuk mengantisi penyebaran covid-19.

Pemberdayaan Desa adat di Propinsi Bali sudah ditetapkan dengan dikeluarkan Keputusan Bersama Nomor :
472/1571/PPDA/DPMA Nomor : 05/SK/MDA-Prov Bali/III/2020 Tentang Pembentukan Satuan Tugas Gotong Royong Pencegahan Covid-19 Berbasis Desa Adat Di Bali yang ditandatangani Gubernur Bali I Wayan Koster dan Ketua Masyarakat Desa Adat Bali Ida Panglingsir Agung Putra Sukahet pada tanggal 28 Maret 2020. Tugas utama Satgas Gotong Royong yakni memberdayakan Krama Desa Adat dan Yowana untuk bergotong royong sesama Krama Desa Adat dalam melakukan pencegahan Covid-19 di Desa Adat secara niskala dan sakala (Humas Provinsi Bali, 2020)

Poltekkes Denpasar merupakan salah satu perguruan tinggi kesehatan yang tentunya memiliki tugas dan peran melakukan pengabdian kepada masyarakat dan perannya sangat dibutuhkan dalam rangka mitigasi pandemic covid-19.

Kegiatan pendampingan dan pemberdayaan masyarakat dapat dilakukan dengan tujuan untuk mendampingi masyarakat dalam proses penguatan potensi masyarakat dan kapasitas desa adat dalam antisifasi penyebaran covid -19 .

Desa Apit Yeh Kecamatan Manggis karangasem dipilih sebagai tempat pengabmas ini karena merupakan salah satu derah zona merah covid -19 dan kemudahan akses informasi dan pendekatan kepada masyarakat di daerah tersebut.

\section{METODE}

Sasaran dari pengabdian masyarakat ini adalah Satgas covid-19 Desa Adat Apit Yeh yang berjumlah 25 orang, dan masyarakat Desa Apit yeh yang terdiri dari 4 banjar yaitu Banjar adat kaler,kangin,kelod dan kawan. Jumlah KK di Desa Adat Apit Yeh 902 KK. Metode yang dipergunakan pada pengabdian masyarakat ini adalah pemberian edukasi kepada satgas covid -19 , penyediaan media dan penyerahan masker untuk diberikan kepada masyarakat oleh satgas covid. Untuk mengukur keberhasilan edukasi yang diberikan dilakukan pengukuran pengetahuan sebelum dan sesudah edukasi dengan menggunakan kuisioner. 


\section{HASIL DAN PEMBAHASAN HASIL}

Pengabdian masyarakat telah dilaksanakan pada tanggal 4 September 2020 dan dilakukan penguatan kembali pada tanggal 11 September 2020. Berdasarkan hasil kegiatan pengabmas yang telah dilakukan, maka dapat dijelaskan sebagai berikut: covid

Pelaksanaan Edukasi tentang pencegahan

Pelaksanaan kegiatan edukasi dilakukan secara luring dengan memperhatikan protokol kesehatan. Satgas covid -19 Desa Adat Apit Yeh yang berjumlah 25 orang dikumpulkan di wantilan (balai adat) yang merupakan tempat pertemuan yang terbuka dengan jarak kursi antar peserta 1 meter. Para satgas semua menggunakan masker dan mencuci tangan sebelum masuk ke wantilan atau aula. Sebelum kegiatan edukasi dimulai, peserta diberikann soal pre test yang berjumlah 10 soal tentang upaya-upaya pencegahan covid-19. Setelah semua mengisi pre test, dilanjutkan dengan pemberian informasi tentang pencegahan Covid 19 dan aturan-aturan adat dan edaran Gubernur Bali terkait sanksi yang akan diberikan kepada masyarakat apabila melanggar protocol kesehatan. Edukasi diberikan dengan menggunakan media slide proyektor. Setelah pelaksanaan edukasi, para peserta diberikan post test untuk mengukur pemahamam peserta terhadap materi yang sudah diberikan. Berikut dipaparkan perubahan rata-rata skor pengetahuan satgas covid 19 sebelum dan sesudah diberikan edukasi.

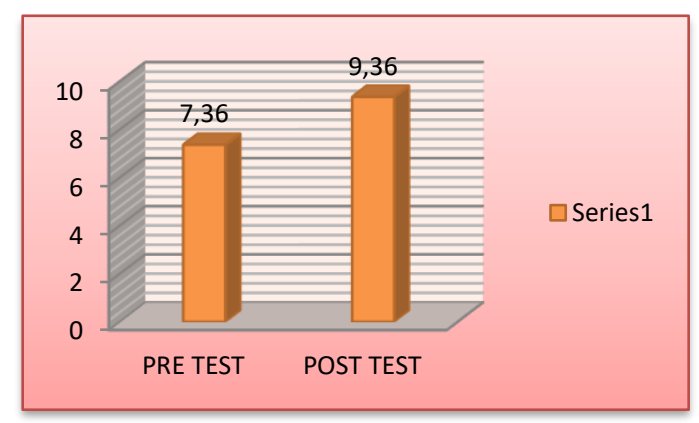

Gambar 1. Rata-rata Skor Pengetahuan Satgas Covid sebelum dan sesudah diberikan edukasi di Desa Apit Yeh 2020

Berdasarkan gambar 1 dapat dijelaskan skor pengetahuan satgas covid-19 Desa Adat Apit Yeh mengalami peningkatan skor dari rata-rata 7.36 menjadi 9.36 setelah diberikan edukasi.

Kegiatan edukasi mampu meningkatkan pengetahuan peserta tentang covid -19. Hal ini sejalan dengan penelitian (Jaji, 2020), yang menemukan adanya peningkatan pengetahuan masyarakat tentang covid-19 setelah diberikan edukasi dengan menggunakan leafleat. Pengetahuan sebelum diberi edukasi menggunakan media leaflet sebanyak $56.27 \%$ terkategori kurang dan pengetahuan setelah di beri penkes menggunakan media leaflet sebanyak 100\% terkategori baik.

Kegiatan edukasi, sosialisasi maupun pengawasan pencegahan covid19 harus dilakukan sesering mungkin dan secara berkesinambungan. Edukasi akan meningkatkan pengetahuan satgas tentang covid -19 , yang selanjutnya akan diteruskan informasi tersebut kepada masyarakat sehingga akan berdampak pada perubahan prilaku menjadi lebih baik. Kegiatan edukasi tentu tidak bisa dilakukan dengan mengumpulkan masyarakat di masa pandemi ini. Bali memiliki suatu lembaga yang disebut dengan Desa Adat. Desa Adat ini memiliki fungsi strategis dan memiliki otoritas dalam mengatur kehidupan masyarakat adatnya. Desa Adat yang lahir karena tuntutan kodrati manusia sebagai mahluk social akan sangat efektif apabila diberdayakan untuk mengantisi penyebaran covid-19.

Publikasi pada media masa di Bali TV dan Bali Post.

Saat kegiatan pengabmas, kegiatan diliput oleh media Bali TV dan disiarkan dalam program seputar Bali. Demikian juga berita tentang pengabdian masyarakat di Desa Apit Yeh Karangasem terbit di halaman Media Bali Post tanggal 9 September 2020.

Poster pencegahan covid -19

Poster pencegahan covid-19 diberikan kepada satgas gotong royong untuk ditempel di tempat-tempat strategis agar mudah dilihat oleh masyarakat. Poster yang berisi pesan-pesan tentang upaya dan hal-hal yang harus dilakukan masyarakat dalam masa new normal untuk mencegah penyebaran kasus covid-19 khususnya di Desa Apit Yeh Karangasem.

Penyerahan Masker 
Sebanyak 950 masker diberikan kepada satgas covid-19 untuk kemudian dibagikan kepada warga, sambil memberikan edukasi agar warga Desa Apt Yeh Karangasem tetap menjaga protocol kesehatan untuk menghindarkan diri dari penularan covid - 19 .

Pemberian penambah daya tahan tubuh untuk satgas.

Tugas utama Satgas Gotong Royong yakni memberdayakan Krama Desa Adat dan Yowana untuk bergotong royong sesama Krama Desa Adat dalam melakukan pencegahan Covid-19 di Desa Adat. Satgas lah yang bertugas mengontrol dan mengingatkan warga agar selalu mematuhi protocol kesehatan dan mencegah penyebaran lebih luas dari covid-19. Untuk menjaga stamina satgas ,maka tim pengabmas Poltekkes Denpasar Jurusan Keperawatan memberikan sembako dan vitamin untuk meningkatkan daya tahan tubuh satgas agar dapat melaksanakan tugas dengan baik.

Evaluasi kegiatan pengabmas dilaksanakan tanggal 11 September 2020. Hasil pemantau di lapangan, poster sudah di pasang di rumah-rumah warga dan tempat strategis. Tidak ada kasus baru di Dessa Adat Apit Yeh Karangasem. Satgas rutin melaksanakan tugasnya untuk mengingatkan warga selalu menjaga protocol kesehatan dalam setiap kegiatan

\section{KESIMPULAN}

Telah dilaksanakan edukasi kepada satgas gotong royong Desa Adat Apit Yeh tentang pencegahan covid-19 dan terjadi peningkatan pengetahuan setelah diberikan edukasi. Untuk mendukung satgas dalam melaksanakan tugasnya, telah diberikan penambah daya tahan tubuh berupa sembako dan vitamin agar para satgas dapat melaksanakan tugas dengan stamina yang kuat. Poster dan masker telah diberika kepada warga melalui satgas gotong royong agar warga tetap patuh menjalani protocol kesehatan.

Diharapkan satgas gotong royong Desa Adat Apit Yeh tetap semangat melaksanakan tugas untuk selalu mengingatkan masyarakat mematuhi protokol kesehatan. Masyarakat Desa Adat Apit Yeh, agar selalu mendengarkan arahan satgas dan selalu mematuhi protocol kesehatan untuk memutus mata rantai penularan covid -19

\section{DAFTAR PUSTAKA}

Humas Provinsi Bali. (2020). Gubernur Bali Bentuk Satgas Gotong Royong Pencegahan Covid-19 Berbasis Desa Adat, Optimalkan Upaya Sekala Niskala. Retrieved from https://www.balinetizen.com/2020/03/30/ gubernur-bali-bentuk-satgas-gotongroyong-pencegahan-covid-19-berbasisdesa-adat-optimalkan-upaya-sekalaniskala/

Jaji. (2020). Pengaruh pendidikan kesehatan dengan media leafletterhadap pengetahuan warga dalam pencegahan penularan covid 19. Proceeding Seminar Nasional Keperawatan 2020, (1), 135139. Retrieved from http://conference.unsri.ac.id/index.php/S NK/article/view/1764

Lam, N., Muravez, S. N., \& Boyce, R. W. (2015). A comparison of the Indian Health Service counseling technique with traditional, lecture-style counseling. Journal of the American Pharmacists Association (Vol. 55). http://doi.org/10.1331/JAPhA.2015.1409 3

LuH Putu Sugiari. (2020). Kasus Transmisi Lokal di Bali Terus Meningkat. Retrieved from https://bali.bisnis.com/read/20200503/537 /1235819/kasus-transmisi-lokal-di-baliterus-meningkat

Poltekkes Kemenkes Denpasar. (2020). Petunjuk Teknis Pengabdian Kepada Masyarakat Poltekkes Kemenkes Denpasar Dalam Masa Pandemi Covid19. Denpasar. 